\title{
No Justice, No Health: the Black Panther Party's Fight for Health in Boston and Beyond
}

\author{
Mary T. Bassett ${ }^{1}$ \\ Published online: 15 November 2019 \\ (C) The Author(s) 2019
}

\begin{abstract}
The Black Panther Party (BPP) evolved from an organization focused on armed selfdefense against police brutality to one that framed police violence as part of broader social violence. Protection meant advocating for a wide range of social and economic rights, including the right to health. In this view, the BPP aligned with a broader tradition of community health from the civil rights movement, women's movement, and other progressive movements. Fred Hampton articulated a radical view that saw the inadequate government social services as a form of oppression. Central to better health was the promotion of social justice and human dignity, incorporated into the BPP "survival programs." In a few short years, the BPP established more than a dozen clinics across the country and a national sickle cell screening program. Its legacy remains relevant today.
\end{abstract}

Keywords Right to health · Black Panther Party · Peoples' Free Medical Clinic · Boston · Community health

\section{Fred Hampton and the Peoples' Medical Care Center in Chicago}

Fifty years ago, on December 4, 1969, Fred Hampton, Chair of the Chicago-based Illinois Chapter of the Black Panther Party (BPP), died in a hail of bullets while asleep in his bed. He was 21 years old. The early morning raid by a combined force of the Chicago Police, a tactical unit of the Cook County State Attorney, and the Federal Bureau of Investigation led also to the death of Mark Clark, another leading member of the Black Panther Party, and seriously wounded several other members who were occupants of the apartment that night. The assault team hauled out survivors, charging them with various violent crimes that were later dropped (Austin 2008, pp. 189-191). A

Mary T. Bassett

Mbassett@hsph.harvard.edu

1 FXB Center for Health and Human Rights, Harvard University, 651 Huntington Ave, 7th FL, Boston, MA 02115, USA 
photograph shows the police carrying out Fred Hampton's body. Some of them are smiling (Film Group 1971).

It had been less than 2 years since Hampton had joined the fledgling Illinois Chapter in 1968, started after Martin Luther King's assassination in April of that year (Austin 2008, pp. 196-197). Hampton soon took a leadership position in Illinois and was in line for national leadership (Austin 2008, p. 198). In the months before his death, he established himself as someone who built alliances, brokering peace between Chicago gangs and seeking to politicize them. He coordinated the beginnings of the original multiracial "Rainbow Coalition," comprised of the Young Lords (Latino), Young Patriots (poor whites), and the Panthers (Williams 2013). Hampton also was excited especially about the opening of a Peoples' Free Medical Clinic on Chicago's impoverished West Side, talking about it in a speech at Northern Illinois University in November 1969. He proudly noted that it was located "there because we know where the problem is at. We know that black people are most oppressed." He also pointed out that it and the breakfast program served all people in need: "the only prerequisite... to receive free medical care is the prerequisite that you be sick." The openness of the programs, he claimed, showed the Panthers' solidarity with (and peaceful intentions towards) others in the struggle: what kind of sense would it make "to get up at 5'oclock in the morning to feed somebody's son and then at 3 o'clock that afternoon shoot him" (Hampton 1977b, p. 11).

The clinic's planning drew Chicago health activists; many of them were veterans of the southern civil rights movement. In spite of Hampton's death, the clinic opened in December 1969. Quentin Young, a physician and long-time Chicago health activist, would recall it served 100 patients a week. The Chicago clinic was named for Spurgeon "Jake" Winters who died in a police shoot out just weeks before the fatal raid that killed Hampton (Young and Fiffer 2016). Many clinics were named for Panthers who died at the hands of police; a clinic in Portland, Oregon would be named for Fred Hampton (Nelson 2011, p. 63). The Chicago chapter had its share, maybe more than its share, of violent encounters with the police, including ones that also led to police injury and police deaths. Hampton himself would have been in no way surprised at the circumstances of his death, but he spent his last days as a superbly effective organizer, seeking multiracial alliances and the establishment of needed services (the medical clinic, free breakfast programs) delivered with dignity and respect.

In this article, I reflect on the Black Panther Party's adoption of health activism to make several observations. First, in its pursuit of health, the BPP found and gained many allies - it did not act alone, but organized in community. Second, the Party's focus on health as a right was grounded in and part of contemporary progressive thinking about how populations come to be healthy or not. Third, the history of the Black Panther Party as a radical project — however short-lived — remains relevant today, both in its conviction that achieving health demands pursuit of social justice and in the lives that it touched, including my own.

The tragically short life of Fred Hampton itself illustrates many of these points. All who knew or encountered him report that he was a charismatic leader, dedicated to a world in which people came before profit, where the marginalized and the poor could find common purpose across the divisions of race. He sought to bring people to the understanding that oppression deprived everyday life of decency and dignity, and to help them see this as the true crime (Film Group 1971; Young and Fiffer 
2016; Hampton 1977ab). The health clinic was part of a larger project: in Hampton's words, "First you have free breakfasts, then you have free medical care, then you have free bus rides, and soon you have FREEDOM!" (Nelson 2011, p. 58).

\section{Reexamining the Activism of the Black Panther Party}

In 1966, Huey Newton and Bobby Seale founded the Black Panther Party in Oakland, California. At a time when police brutality was a longstanding, regular occurrence in Black communities, the Black Panther Party determined to "give as good as it got." For this, it paid with some 20 lives lost to gun battles, usually during police raids. "You shoot at me, I'll shoot back," Huey Newton is reported to have said (Seale 1970/Seale 1991, p. xii). This established a reputation for unflinching armed militancy that has dominated contemporary perceptions of the Black Panther Party. Today, its iconography remains emblazoned on popular imagination - its youthful members with their dark sunglasses, black leather jackets, and black berets, marching in formation, visibly bearing arms. As I wrote in an earlier short reflection, these images "in no way capture the organization's historical significance or its lasting contribution to public health" (Bassett 2016).

Recent years have seen the emergence of new scholarship that seeks to unite the Black Panther Party's militant challenge to police with its later commitment to addressing community social needs (Austin 2008; Jeffries 2007; Jeffries 2010; Jeffries 2018; Jerome 2019; Lazerow and Williams 2006; Murch 2010; Newton Foundation 2008; Williams 2013; Williams and Lazerow 2008). For some, this evolution reflected a decline in militancy; others see the "survival programs" as enabling communities both to survive and to envision a society that put people at the center of its agenda, part of the often-repeated commitment to put theory into practice. While the newer works all recount establishment of free medical clinics as part of community service, Alondra Nelson (2011) has focused most explicitly on health-related activities. Then, Alfredo Morabia, Editor-in-Chief of the American Journal of Public Health (2016), devoted a special section of the journal to the public health legacy of the Black Panther Party. Jessica Jerome (2019) has written about how these free health clinics differed from the contemporary Federal Qualified Health Centers, which often claim their legacy as the free health clinic movement. Although unique in its combination of militant response to state oppression and community rootedness, the Black Panther Party also worked with other groups. These included fraternal organizations (like the Young Lords), groups emerging from the modern civil rights movement (such as the Student Nonviolent Coordinating Committee), and allied formations on the "New Left," including the Medical Committee for Human Rights (MCHR) (Jeffries 2018; Lazerow and Williams 2006).

This period of Panther activity (1966-1982) also overlapped with anti-colonial national liberations struggles in Africa and Asia. Many of these movements embraced Marxism-Leninism and socialism, and were another way that the BPP members were exposed to these views. Fred Hampton put it plainly in his speeches: "We're not going to fight racism with racism, we're going to fight racism with solidarity. Even though you think you ought to fight capitalism with Black capitalism, we're going to fight capitalism with socialism" (Hampton 1977a). Delegations traveled to Cuba and to 
China. It was not an accident that when fleeing the USA, exiled Panthers looked to Cuba and newly independent African countries (Algeria, Tanzania) for shelter.

In just a few years after its founding, the Party extended its idea of protecting the Black community from genocide through self-defense against police violence to a far broader concept of what threatened the lives of Black people. In this view, lack of adequate housing, education, and jobs also threatened Black communities with extinction. The Party proclaimed the need to organize in self-defense against these injuries as well. Protection came in the form of "survival programs," not guns. Critical to its commitment to service was the idea that recipients be educated to understand that they deserved such support, that support was not charity but solidarity, and that the goal was community empowerment to claim what a just government should provide. Free breakfast programs were the best known, but activities variously included free transport to prisons and jails, a free school in Oakland, weekly political education classes, access to advice on public benefits eligibility, and free legal services (Newton Foundation 2008, pp. 1-80). A key activity was establishment of free medical clinics.

\section{Community-Based Health Care to Radical Health Movement}

The modern US movement for community health among the disenfranchised and the poor began with the civil rights movement and extended to other groups (the national farmworkers movement, for example). Efforts to gain African American voting rights in the American South unleashed a violent response from state and local authorities as well as civilian groups (such as the Ku Klux Klan). Black civil rights leadership reasoned that an integrated effort with shared presence of Whites, mostly from the north, would propel this repression into public view. Indeed, ensuing violence during "Freedom Summer" in 1964 gained a broader audience. The need for medical aid also emerged, because the segregated southern hospitals could not be relied upon to serve civil rights workers (Nelson 2011, pp. 34-36). In fact, not only hospitals but also all of US medicine remained deeply segregated. The American Medical Association (AMA) invoked state rights as a basis for non-interference in its southern chapters' decisions to exclude Black doctors. To counter this, the Medical Committee for Civil Rights formed to protest AMA segregationist policies. Activities included picketing an AMA annual meeting, joining the March on Washington, and offering medical care to civil rights workers. This committee later evolved into the Medical Committee for Human Rights (MCHR) (Dittmer 2009). In 2008, the AMA issued a formal apology for the exclusion of Black doctors for over a century (Davis 2008).

The health workers who went south found much to alarm them. Time in the Mississippi Delta and other rural areas of the American south revealed the shocking health status of the Black population. What began as an effort to tend to the health needs of civil rights workers soon extended to addressing the health of impoverished Black communities that lacked access to services. MCHR, often working with the Student Nonviolent Coordinating Committee, took up the need to have health care services and the idea of community clinics began (Dittmer 2009). Mound Bayou clinic would open with a wide array of services as part of its health care efforts, including employment, child care, job training, food production, legal services, and transport. Further, community members created local health councils across the county. The presence of 
community members helped broaden the array of services viewed as necessary resources for health, such as public transport services and a farming cooperative (Ward Jr. 2017).

It was in this context that the Black Panther Party began to champion health as a human right. At its founding in 1966, the Black Panther Party declared "what we want" and "what we need" with demands for freedom, housing, education, and an end to police violence and incarceration summarized in its guiding document - the "Ten-Point Program" (Black Panther Party 1966). Although its actions initially focused on police violence, the Party already had a holistic view.

The 1966 version of the Ten-Point Program/Platform did not directly mention health, but the Panthers were soon thinking about and acting on health in their communities. By 1969, the Panthers had opened the first Peoples' Free Health Clinics in Kansas City and by 1970, leadership had mandated all chapters to establish free clinics (Nelson 2011). The 1972 revision of the Ten-Point Program formally added health as the sixth point:

\section{We Want Completely Free Health Care for All Black and Oppressed People}

We believe that the government must provide, free of charge, for the people, health facilities which will not only treat our illnesses - most of which have come about as a result of our oppression-but that will also develop preventative medical programs to guarantee our future survival. We believe that mass health education and research programs must be developed to give Black and oppressed people access to advanced scientific and medical information, so we may provide ourselves with proper medical attention and care (Black Panther Party 1972).

The revised Ten-Point Program now referred to "Black and oppressed people," not just Blacks.

The Ten-Point Program shares both language and sentiment with the US Declaration of Independence, from which it quoted, and with the Congress Alliance Freedom Charter, articulated in 1955 to guide the next nearly 40 years of the 80-year fight against South African apartheid. The Freedom Charter proclaimed that government would be responsible for free health care, both preventive and curative (Alliance Congress 1955). As Alondra Nelson (2011) and others have pointed out, the Black Panther Party drew from an international activist literature including Martinique's Frantz Fanon and China's Mao Tse-Tung, and invoked international bodies, such as the United Nations and the World Health Organization. The language the Panthers used to discuss the right to health echoes that of the Constitution of the World Health Organization (1946): "The enjoyment of the highest attainable standard of health is one of the fundamental rights of every human being without distinction of race, religion, political belief, economic or social condition."

Consequently, when the Black Panther Party took up the right to health, there was a pool of willing doctors and other health workers - Black and White - many of whom were veterans of the modern civil rights movement and committed to health care as a right and not a privilege. They shared the Panthers' fundamentally radical idea that achieving "health for all" demanded a more just and equitable world. To model ways in 
which such a world might work, putting "theory into practice" the Panthers opened free health clinics across the country. More than a dozen were established between 1968 and 1973 in cities across the USA, including Boston, Berkeley, Chicago, Cleveland, Kansas City, Seattle, Portland, Los Angeles, New Haven, Milwaukee, and Philadelphia.

\section{The BPP, the Boston Peoples' Free Health Center, and My Journey to Public Health}

The Black Panther Party was a critical step on my path to medicine and public health. As a high school student at the Fieldston School (and part of the 1970 Black student takeover there), I started going around the Black Panther Party office in Harlem. A fleeting image of me (and my brother) at a political education class appears in the documentary "Black Power: Mixed Tape" (Olsson 2011). As a newly enrolled college student at Harvard, I looked up the Boston chapter and began volunteering at the Franklin Lynch Peoples' Free Medical Center in Roxbury, Massachusetts. The Bay State Banner, the local Black newspaper, reported that on May 31, 1970, about 100 people gathered to inaugurate the clinic (Baber 1970). The clinic took its name from a young man who died at the hands of police, reportedly shot dead while hospitalized. The Black Panther Party joined with the Black United Front/Operation Stop to site the clinic (housed in a trailer) on a stretch of land earmarked for the construction of an interstate highway.

Roxbury, like many Black neighborhoods, was subject to urban renewal projects that cleared land for highways or other projects. Residents argued that the highway would further isolate and divide this predominantly Black neighborhood and community protests blocked its construction (MacLaury et al. 2018). I wrote an article for the Black Panther, with the title "People Before Highways" (Bassett 1971) in echo of the neighboring rally cry.

The mother of Franklin Lynch spoke at the dedication of the clinic, as did Donna Howell, a Black Panther Party member, "calling the clinic, an alternative to the bad health care in this neighborhood." The paper described clinic activities:

The clinic will offer, absolutely free, the services of a family doctor, including checkups, immunizations, blood tests and health education. A major emphasis of the clinic will be on preventive medicine. People will be encouraged to have regular checkups and to come to the clinic at the first sign of medical troubles....

In addition, classes in first aid and laboratory techniques will be given at the clinic. The clinic is staffed with volunteer professional and non-professional people from hospitals in the area and from the community. (Baber 1970)

In July 2019, I spoke with two of the clinic's doctors in the 1970s-Dr. Gerald Friedland, MD and Dr. John David, MD - about their recollections of the clinic. Dr. Friedland served as the doctor of record for the clinic. He recalled how four people (including Donna Howell who was the key Panther overseeing the clinic) traveled outside of Boston to lease a trailer. The group aroused the obvious curiosity of the vendors. In any case, the four selected a trailer and the company delivered it as requested to a strip of land that had been cleared for the planned highway, near the intersection of Ruggles and Tremont Streets (Fig. 1). The trailer housed a reception desk, waiting area, lab bench, and an examining room. 


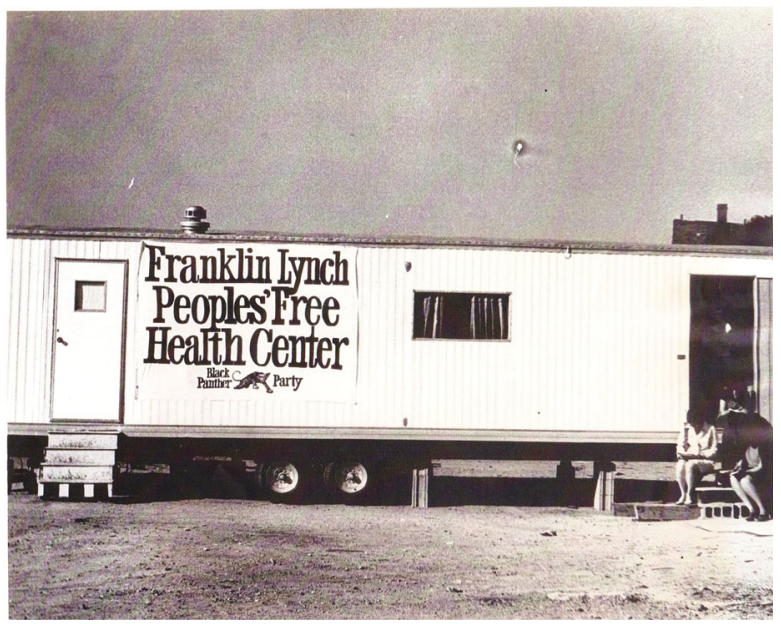

Fig. 1 The Black Panther Party's Franklin Lynch Peoples' Free Health Center, circa 1970, Boston, MA. Courtesy of It's About Time Archives (http://itsabouttimebpp.com)

Dr. Friedland recalled that equipping the clinic relied on donations and came with other challenges: electricity had to be tapped from a nearby streetlamp. Dr. David learned about the clinic at a meeting held at the Harvard Medical School library addressed by Party members seeking to recruit volunteer doctors. He volunteered, with the knowledge of his department chair. No one raised any objections, although both doctors believed their roles attracted the interest of the FBI. The clinic's hours were on weekdays from 7-11 PM. Dr. David saw patients on the same evening each week (the same evening that I volunteered), so it was easy to arrange patient follow-up. As a basic science researcher, he enjoyed a return to primary care. His specialty practice clinics saw a handful of patients, quite a contrast to the 20 patients or so he might see on his clinic night. Both doctors recalled the donation of clinical referral services, including lab work and radiology by Harvard-affiliated hospitals. Pediatric referrals were accepted by Boston Children's Hospital. Pharmaceutical companies also donated drugs. One company offered its entire drug list at no charge.

I was not a Party member, but I was given assignments. The first was to schedule doctors, all of whom were also volunteers, to staff the clinic. Later, I would learn that they were all well-regarded academics (a description that included Dr. Friedland and Dr. David) who were on staff at well-known Boston area medical schools. I am sure they were busy, but I cajoled, bullied, and begged and filled the roster each week. I was 18 years old.

Then, I was assigned to run the sickle cell screening program. The Black Panther Party had learned about sickle cell anemia, a neglected genetic disease that in the USA affected mainly people of African descent. Although it had been identified in 1910 (Serjeant 2010), it attracted little public attention and even less funding. It is about as common as cystic fibrosis, a genetic disease that occurs mainly among Ashkenazi Jews. Treatment of sickle cell disease was extremely limited, as it is to this day. There was a rapid screening test (brand-named Sickledex, then produced by Ortho Pharmaceuticals) based on a simple finger stick. But the test was not widely employed. The Black 
Panther Party rectified this government failure to act by setting up a national screening program.

I recruited Boston area Black pre-med students to perform the screening test (see Fig. 2). As it happened, my father was able to organize donations of the Sickledex test kits, as was a high school friend. When it became clear that the weekly search for test kits would be burdensome, I turned to Bill Wallace, one of a handful of Harvard Black graduate students in biology. He developed a homemade test. ${ }^{1}$ On Friday evenings, I would go up the lab to weigh out the mixture and test it against controls. That same evening, Panther members leafleted public housing buildings to alert them that testing was coming. Each Saturday about a dozen white-jacketed doctors-to-be went door-todoor and offered testing in people's homes. Area hospitals provided follow-up for those who screened positive, performing hemoglobin electrophoresis (the definitive test). They also referred all confirmed to have a sickle cell gene for genetic counseling. The sickle cell screening program was a lesson in community health that has never left me. It was more than just a service - it was an organizing tool.

The Black Panther Party was a key driver of a growing focus on sickle cell anemia, which led to needed increased investments in research and care (and even a law, the National Sickle Cell Anemia Control Act, passed in 1972 and since updated). Over time, the pre-med volunteers, including me, came to consider the Black Panther Party's focus on sickle cell anemia as a complicated choice. The sickle cell trait (when a person had a sickle gene from only one parent) offered some protection against malaria and linked the US Black population to its long ago African past. It was unrelated to socalled lifestyle choices that contributed to the risk of many common diseases. Victims were truly blameless - it was in their genes. In other settings, the Party had argued forcefully against a genetic conception of race, and the notion that excess ill health among Blacks reflected a genetic predisposition, rather than social conditions (Nelson 2011, pp.159-180). Additionally, sickle cell disease contributed relatively little to the disease burden borne unfairly by Blacks (Williams and Jackson 2005). We worried that the Nixon administration's embrace of sickle cell anemia as a priority wrongly portrayed Black ill health as genetic in origin. In any case, the Black Panther Party's presence in health would soon dwindle. In 1972, the Boston chapter began to lose its vitality as members were summoned to the Bay Area headquarters and the chapter soon closed.

\section{The BPP Legacy}

The Franklin Lynch Peoples' Free Health Center soon also closed. It left more than a legacy of service, continued in Boston's rich endowment of neighborhood clinics located in poor neighborhoods that became Federally Qualified Health Centers. The proposed highway that the clinic trailer blocked was never built. The clinic also left a legacy of community collaboration, of viewing health as an outcome of a broad range of resources for everyday life. As MacLaury et al. (2018, p. 126) write, the Boston chapter "modeled a society controlled by the community members, caring for each

\footnotetext{
${ }^{1}$ Although Wallace said he had published his methods, I could not locate the publication when I looked recently.
} 


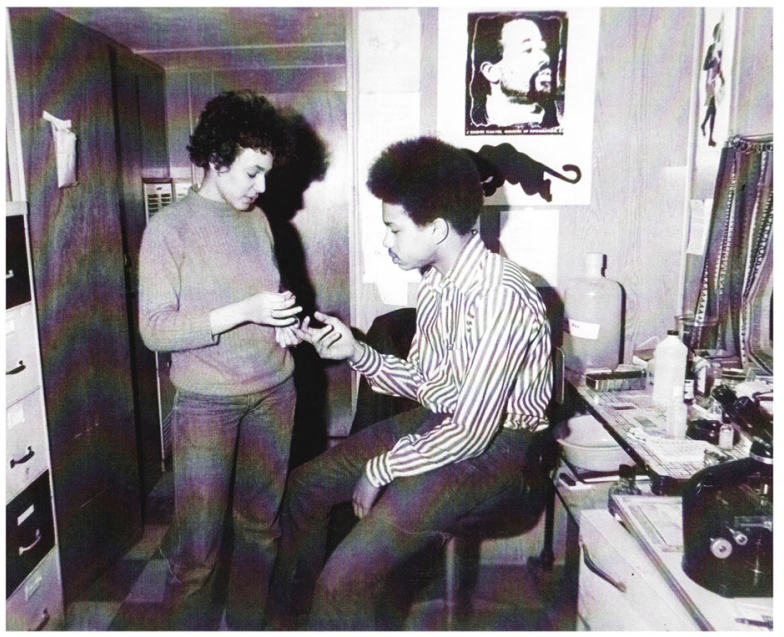

Fig. 2 Mary T. Bassett (left) demonstrating a finger stick for sickle cell screening at the Black Panther Party's Franklin Lynch Peoples' Free Health Center, circa 1970, Boston, MA. Courtesy of It's About Time Archives (http://itsabouttimebpp.com)

other and constantly striving to ameliorate suffering, most excellently modeled by the Franklin Lynch People's Free Medical Center."

In education sessions led by party members, we pre-med students read and heard about the barefoot doctors of China and the heroic sacrifice of Norman Bethune, the Canadian surgeon who served along the Red Army. We learned to critique race science and how the US health care system used poor people as "clinical material" and was too often driven by profit motives. We learned also the humility of knocking on doors and sitting down to talk with people in their homes. We learned confidence and pride. Lessons once learned that are hard to lose. Many of us went on to become doctors.

The FBI considered the BPP a major threat not only because of the berets and guns that so effectively propelled these beautiful, young Black people into public view, but because of its challenge to systemic inequity, which highlighted government failure to deliver on legal rights and social protection for Black communities. More than a dozen Panther Party members remain imprisoned over five decades later. Their slogans, "Off the Pigs" and "Serve the people body and soul," combined to unleash a staggering government response, including the reprehensible intervention of J. Edgar Hoover's FBI in the form of the now infamous COINTELPRO that saw the leadership arrested, jailed, and killed.

No one was ever charged with the execution of Fred Hampton. Thirteen years following his death, after a protracted legal effort, the circumstances surrounding the raid led to a financial settlement with the victims' families (Austin 2008, p. 223). In the Chicago suburb of Maywood where Hampton protested against the town's segregated pool, the public swimming pool bears his name and a statue in his likeness (Atlas Obscura nd; Romain 2015), as does a mural in Chicago (Chicago Sun Times 2019). But more importantly, his words and example are now often invoked by a new generation of activists, such as the Blackout for Human Rights event where the actor Michael B. Jordan recited Hampton's speech, "Power Anywhere There's People" (Pablo Production 2016). 
Retrieving the history of the Black Panther Party as a proponent and provider of health as a human right in the community speaks to conditions that endure into the present day. In a recent paper, my colleagues Williams et al. (2019, p. 105) note "the striking persistence of racial/ethnic inequities in health and the empirical evidence that indicates that socioeconomic factors alone do not account for racial/ethnic inequities in health." Racial disparities in health continue and in some cases are widening (for example, Institute of Medicine 2003; Tikkanen et al. 2017). Police violence continues (for example, Feldman et al. 2017; Merrefield 2019). There remain too few people of color in the health professions, and health care delivery remains plagued by racist ideas (Williams et al. 2019; Saini 2019). Although the terms are different, the new trend of "task shifting" refers to the engagement of lay people in delivering health services, pioneered also in the Peoples' Free Medical Clinics. Threats to health persist in rising income inequality, growing explicit expressions of white supremacy, and failure to ensure access to health care for millions of Americans. The Centers for Disease Control and Prevention recently announced that in 2017 for the third year in a row, after a century of year -on -year improvements, US life expectancy has declined and there continues to be a gap of 3.5 years in life expectancy between Black and White populations in the USA (Arias and Xu 2019, p. 1, 5).

While the Black Panther Party eventually disbanded in 1982, it popularized a set of beliefs that identified health as a social justice issue for Blacks and the poor that has influenced public health to this day. Its militancy, blending science with community engagement, resonates today under the banner of \#BlackLivesMatter. That health is a right, not a privilege, remains true. It is a proud legacy, one built by many, still unachieved, and still worth fighting for today.

Acknowledgments The author would like to thank Susan Lloyd McGarry, who brought her editorial wizardry to this manuscript and to Sarah Perl who helped to procure the photos. Alfredo Morabia, editor of the American Journal of Public Health, first asked me to write on this topic as part of a special section in that journal. He graciously allowed some of the phrasing from that paper (Bassett 2016) to appear here. The author would also like to thank Gerald Friedland, MD and John David, MD for generously sharing their recollections of the Franklin Lynch Peoples' Free Medical Center and for their many years of work for a better world.

Open Access This article is distributed under the terms of the Creative Commons Attribution 4.0 International License (http://creativecommons.org/licenses/by/4.0/), which permits unrestricted use, distribution, and reproduction in any medium, provided you give appropriate credit to the original author(s) and the source, provide a link to the Creative Commons license, and indicate if changes were made.

\section{References}

Alliance Congress, South Africa (1955). The Freedom Charter, adopted at the Congress of the People, Kipstown, South Africa, June 26, 1955. University of KwaZulu-Natal, Gandhi-Luthuli Documentation Centre website. Retrieved August 25, 2019 (http://scnc.ukzn.ac.za/doc/HIST/freedomchart/freedomch. html).

American Journal of Public Health (AJPH) (2016). AJPH Special Section: Black Panther Party. AJPH, $106(10), 1732-1757$.

Arias, E., \& Xu, J. (2019). United States Life Tables, 2017. National Vital Statistics Reports, 68(7).

Atlas Obscura (N.D.). Maywood Illinois: Fred Hampton Pool. Retrieved September 5, 2019 (https://www. atlasobscura.com/places/fred-hampton-family-aquatic-center).

Austin, C. (2008). Up against the wall: violence in the making and unmaking of the Black Panther Party. Fayetteville: University of Arkansas Press. 
Baber, L. (1970). Dedicated to Franklin Lynch: Black Panther Health Clinic opens in Roxbury. Bay State Banner, June 4, 1970, 6(38,:1).

Bassett, M. T. (originally anonymous) (1971). People Before Highways. The Black Panther, 6(30),7, 19.

Bassett, M. T. (2016). Beyond berets: the Black Panthers as health activists. American Journal of Public Health, 106(10), 1741-1743.

Black Panther Party (1966). The Black Panther Party Ten-Point Platform and Program: What We Want, What We Believe. October 1966. It's About Time: Black Panther Party Legacy and Alumni website. Retrieved August 22, 2019 (http://www.itsabouttimebpp.com/home/bpp_program_platform.html).

Black Panther Party (1972). The Black Panther Party Ten-Point Program, March 29, 1972 Platform: What We Want, What We Believe. Pp. 75-77 in The Black Panther Party: Service to the People Programs, edited by D. Hilliard for the Dr. Huey P. Newton Foundation. Albuquerque: University of New Mexico Press.

Chicago Sun Times (2019). West Side mural recalls Black Panthers leader Fred Hampton, killed by police 50 years ago. August 23, 2019. (https://chicago.suntimes.com/murals-mosaics/2019/8/23/20692288/fredhampton-black-panthers-mural-west-side-50-years-ago).

Davis, R. M. (2008). "AMA Apology to African Americans." Delivered at Annual Meeting of the National Medical Association, July 30, 2008, Atlanta GA. Retrieved August 22, 2019 (https:/www.ama-assn. org/about/ama-history/history-african-americans-and-organized-medicine).

Dittmer, J. (2009). The Good Doctors. The Medical Committee for Human Rights and the Struggle for Social Justice in Health Care. New York: Bloomsbury Press.

Feldman, J., Gruskin, S., Coull, B. A., \& Krieger, N. (2017). Quantifying underreporting of law-enforcementrelated deaths in United States vital statistics and news-media-based data sources: A capture-recapture analysis. PLoS Medicine, 14(10), e1002449. https://doi.org/10.1371/journal.pmed.1002399.

Film Group, The. (1971). The Murder of Fred Hampton. Chicago: Documentary Film. Directed by H. Alk.

Hampton, F. (1977a). Comment: Fred Hampton Speaks, Excerpts from a July 1969 Speech. The Black Panther, December 3, 1977, pp. 2, 28.

Hampton, F. (1977b). It's a Class Struggle, Goddammit! Transcript of Speech given at Northern Illinois University November 1969. Vita Wa Watu: New Afrikan Theoretical Journal, 11, 8-21.

Institute of Medicine (US) Committee on Understanding and Eliminating Racial and Ethnic Disparities in Health Care. (2003). In B. D. Smedley, A. Y. Stith, \& A. R. Nelson (Eds.), Unequal Treatment: Confronting Racial and Ethnic Disparities in Health Care. Washington, DC: National Academies Press.

Jeffries, J. L. (Ed.). (2007). Comrades. Bloomington: Indiana University Press.

Jeffries, J. L. (Ed.). (2010). On the Ground: the Black Panther Party in Communities across America. Jackson: University Press of Mississippi.

Jeffries, J. L. (Ed.). (2018). The Black Panther Party in a City near You. Athens: University of Georgia Press.

Jerome, J. (2019). Much more than a clinic: Chicago's Free Health Centers 1968-1972. Medical Anthropology, epub ahead of print, July 11, 1-14. doi: https://doi.org/10.1080/01459740.2019.1633641.

Lazerow, J., \& Williams, Y. (2006). In Search of the Black Panther Party: new perspectives on a revolutionary movement. Chapel Hill, NC: Duke University Press.

MacLaury, D., Jeffries, J. L., \& Nicklas, S. (2018). The Black Panther Party and Community Development in Boston. In J. L. Jeffries (Ed.), The Black Panther Party in a City near You (pp. 89-136). Athens: University of Georgia Press.

Merrefield, C. (2019). Black men 2.5 times more likely than white men to be killed by police, new research estimates. Journalist's Resources, Harvard Kennedy School of Government website, August 5, 2019. Retrieved August 25, 2019 (https://journalistsresource.org/studies/government/criminal-justice/killedpolice-black-men-likely-white-men/). August 25, 2019

Murch, D. J. (2010). Living for the city: migration, education, and the rise of the Black Panther Party in Oakland, California. Chapel Hill, NC: University of North Carolina Press.

Nelson, A. (2011). Body and soul: the Black Panther Party and the fight against medical discrimination. Minneapolis, MN: University of Minnesota Press.

Newton Foundation, \& Dr, H. P. (2008). In D. Hilliard (Ed.), The Black Panther Party: service to the people programs. Albuquerque: University of New Mexico Press.

Olsson, Göran, dir. (2011). The Black Power Mixtape 1967-1975, documentary film, produced by A. Rogell. Sweden.

Pablo Production (2016). Michael B. Jordan Recites Fred Hampton Speech \#MLKNOW, filmed by P. Fant. Retrieved August 25, 2019 (https://www.youtube.com/watch?v=MnCK8wBAiKw).

Romain, M. (2015). Remembering Fred Hampton's fight to swim — 45 years later. Village Free Press, June 24, 2015. Retrieved August 25, 2019 (https://thevillagefreepress.org/2015/06/24/remembering-fredhamptons-fight-to-swim-45-years-later/)

Saini, A. (2019). Superior: the return of race science. Boston: Beacon Press. 
Seale, B. (1991, reprint of Random House 1970 edition). Seize the time: the story of the Black Panther Party and Huey P. Newton. Baltimore: Black Classic Press.

Serjeant, G. R. (2010). One hundred years of sickle cell disease. British Journal of Haematology, 151(5), 425429.

Tikkanen, R. S., Woolhandler, S., Himmelstein, D. U., Kressin, N. R., Hanchate, A., Lin, M., McCormick, D., \& Lasser, K. E. (2017). Hospital payer and racial/ethnic mix at private academic medical centers in Boston and New York City. International Journal of Health Services, 47(3), 460-476. https://doi. org/10.1177/0020731416689549.

Ward Jr., T. (2017). Out in the rural: a Mississippi Health Center and its war on poverty. New York: Oxford University Press.

Williams, J. (2013). From the bullet to the ballot: the Illinois Chapter of the Black Panther Party and Racial Coalition Politics in Chicago. Chapel Hill, NC: University of North Carolina Press.

Williams, D. R., \& Jackson, P. B. (2005). Social sources of racial disparities in health. Health Affairs, 24(2), 325-334. https://doi.org/10.1377/hlthaff.24.2.325.

Williams, Y., \& Lazerow, J. (2008). Liberated territory: untold local perspectives on the Black Panther Party. Chapel Hill, NC: Duke University Press.

Williams, D. R., Lawrence, J. A., \& Davis, B. A. (2019). Racism and health: evidence and needed research. Annual Review of Public Health, 40, 105-125.

World Health Organization (1946). Constitution. Adopted in New York City, July 24, 1946. Text from WHO website. Retrieved August 25, 2019 (https://www.who.int/about/who-we-are/constitution).

Young, Q., with S. Fiffer (2016). Quentin Young on the Black Panther Party Free Clinic in Chicago. American Journal of Public Health 106(10), 1754-1755. [Excerpted from Young, Q. (with S. Fiffer). Everybody In, Nobody Out: Memoirs of a Rebel Without a Pause. Friday Harbor, WA: Copernicus Healthcare, pp. 114 118, 2013.]

Publisher's Note Springer Nature remains neutral with regard to jurisdictional claims in published maps and institutional affiliations. 